\title{
Determining Influence Of Teacher's Workload On Academic Performance In Secondary Schools, Suba Sub-County Kenya
}

\author{
Adika Berda Rose \\ Department of Education Management and Foundation, \\ Maseno University, P.O.Box Private Bag, Maseno, Kenya. \\ James Ochieng Sika \\ Department of Education Management and Foundation, \\ Maseno University, P.O.Box Private Bag, Maseno, Kenya.
}

\begin{abstract}
Education all over the world is regarded as key to overall national development as it improves productive capacity of its citizens. Academic performance in terms of grades and mean score may be a yardstick propelling students from secondary schools to acquire university education. Teachers play a significant role towards academic performance and therefore their workloads may affect academic performance. In Suba Sub - County, in the period $2012-2015$ percentage pass in KCSE was $36.2 \%, 26.46 \%$ and $36.76 \%$ while the mean grade was $4.6,4.7$ and 3.9 respectively. The neibouring sub - county performance was higher in terms of students with $C+$ and above and the mean grade respectively. The objectives of the study was to determine the influence of teacher workload on student's academic performance in secondary schools in Suba Sub-County. The study used descriptive and Correlation survey design. The Study population comprise 33 secondary schools with 33 Head teachers, 164 teachers and 1,035 form four students. Stratified sampling was used to determine sample size which comprised of 311 form four students 49 teachers and 30 head teachers in the four existing zones; Kigoto, Gwassi, Kiabuya and Central. The study revealed that influence of teacher's workload on academic performance was significant $(r=.523, N=154$, $\mathbf{p}<0.01$ ) and also that for every one unit increase teacher workload, there was a decrease in pupils academic achievement as signified by the coefficient $(-.558)$. The study concluded that it is important to reduce workload with tighter control in monitoring attendance to teacher's in classroom. The study recommended that all stakeholders be involved in enhancing students academic performance and the teachers' observe best practices in performance of their duties.
\end{abstract}

Key Words: Academic ; Performance; Teacher; Students; Workload

\section{INTRODUCTION \& BACKGROUND OF THE STUDY}

In New Zealand, secondary schools have showed have varied workloads. The survey conducted by Ingverson et al (2005) showed that senior managers (including principals and deputy principals) reported working on average 59 hours per week, middle managers (heads of departments) worked 52 hours per week while teachers' worked at 47 hours per week. In this survey the number of hours spent at schools contributed significantly to poor performance of all teachers in the schools due to increased stress levels. The survey concluded that teachers and schools must develop a range of strategies to facilitate management of workloads, e.g prioritizing tasks, using support staff, minimizing the number of meetings, "filtering" the demands of outside agencies.

According to the 'Report of the Task on secondary schools fees 2014', the government proposes enforcement of a policy requiring that no class has more than 45 students. It also recommends that each school should have a maximum of three stream per class. The team however proposed that secondary school teachers should handle a minimum of 32 lessons of 
40 minutes per week. This would translate into 22 hours per week in line with proposed TSC staffing norms, says the report. A study by Koech, Tikoko and Chemwei (2014) indicates that a number of schools factors are responsible for high teacher turnover in Kenya. This includes heavy workload and non - payment for extra - work hours leading to high teacher turnout and poor performance. Though this study looked at the institutional factors, the methodology and some data pertinent teachers performance were omitted for example workload per week and recent TSC requirement which is now 30 lessons per week

The Students academic achievement in Suba Sub-County between the years 2012-2015 is averagely at a mean grade of 5.1 which is below average compared to the maximum KNEC grading 12.00. This exists despite the fact that secondary schools select students from the same pool of primary schools. They are provided with adequate and well trained teachers and also financed by the same government. The teachers and head teachers usually have the responsibility of setting clear visions for the Students through setting of subject targets. This usually demands teachers continued involvement with students and self-drive. Table 1 shows summary of Homa-bay county KCSE performance from 2012-2015 as per KNEC results:

Table 1: Homa - Bay County Academic Performance in KCSE Mean Scores

\begin{tabular}{lcccccc} 
Sub - County & $\mathbf{2 0 1 2}$ & $\mathbf{2 0 1 3}$ & $\mathbf{2 0 1 4}$ & $\mathbf{2 0 1 5}$ & average & percent \\
Homa Bay & & & & & & \\
Rachuonyo South & 6.197 & 6.337 & 6.8044 & 6.9761 & 6.578 & $58.35 \%$ \\
Mbita & 5.120 & 5.649 & 6.0236 & 6.3456 & 5.864 & $50 \%$ \\
Rachuonyo North & 4.000 & 5.423 & 5.8060 & 5.9382 & 5.2918 & $41.67 \%$ \\
Suba & 4.480 & 5.247 & 5.3181 & 5.7524 & 5.19937 & $41.67 \%$ \\
Ndhiwa & 5.248 & 4.141 & 4.9579 & 5.2733 & 4.90505 & $41.67 \%$ \\
\hline
\end{tabular}

Source: Homa Bay County Education Office, Homa Bay (2015)

Suba sub-county is at position 5 with a mean grade of 5.199 showing the probability of the candidates continued below average performance.

\section{Statement of the Problem}

The effects of teacher excessive workload goes beyond poor scholastic outcomes to include economic and social costs. In schools, heavy workload has a monetary cost to the authorities with regard to substitute teachers. A small but growing volume of research on teachers' excessive workload indicates that this problem is particularly severe among secondary school teachers in underdeveloped nations (Alcazar et al., 2006; Chaudhury, Hammer, Kremer, Muralidharan and Rodgers, 2006). Thus the impact of teacher excessive workloads is real and hence the need to dig into its causes with a view to addressing it to improve secondary school outcomes. Reducing teacher workload will mean a improve results at secondary level. Although earlier work to identify the causes of teacher excessive workload focused on analyzing individual-level characteristics, such as age, gender, or years of experience to explain these teacher factors (Muchinsky, 2007; Steers \& Rhodes, 2008), not much has been done to determine their influence on academic performance. The specific objective of the study was to determine the influence of teacher workload on student's academic performance in secondary schools in Suba Sub-County.

\section{LITERATURE REVIEW}

In South Africa, Gerhard (2005) identified workload as a factor that influences the teachers negatively. The perception, decision and intention of the teacher as regards workload are 
personal and challenging; every decision in the school is expected to be towards the goal and the objective of a school. The teachers are the major leads in instilling knowledge to the student's; a high workload may therefore have negative effects on performance. Badenhost in his book the problem with south African schools (2005-2010), proposes reduction of workload to be one teacher per 40 students.

The teachers are therefore expected to put effort in order to ensure good performance of the student's. In 2003, a study done in New Zealand by National Survey of Secondary Schools found that workload among principals and a teacher was high. The principal was found to be working an average of 67 hours per week above class contact time. Most teachers and principals wanted a reduction in the amount of paper work. The teachers were asking for curriculum changes and most of them preferred to work at home. A similar view was reported by Lawrence, Kleinhenz, Bearis and Wilkinson (2005), in a research study on how the work of teachers could be more effectively structured to support effective teaching and learning in relation to workload, found out that high workload affected teacher quality.

Workload determines the teacher behavior and quality of teaching. This is seen in a research by Price Waterhouse Coopers (2001) in the UK. They carried out a study between (March 2001 and December 2001). The purpose of the study was to identify the main factors that determine the workload of teachers and head teachers and to develop program of action to manage workload effectively. The findings were that $75 \%$ of the teachers reported that workload was heavy, $71 \%$ that workload was affecting the quality of their teaching and $47 \%$ it was affecting their health. Poor health has a relationship with absenteeism. Poor health is not necessarily physical but also emotional and psychological. Teacher workload in Kenya is high; the Ministry of Education theoretical expectation is that the maximum teacher workload in secondary schools is 30 lessons per week. On the practical side; this depends on the availability or shortage of teachers.

Suba Sub-County for example had a teacher shortfall of 32. 7\% and transfer request of 37.8\% (Ministry of Education, Suba Sub-County office, 2012). Just like in New Zealand, the teacherstudent contact hours in Kenya is an average of 67 hours per week, occasioned by long syllabus that should be all taught within the year; that has led to teachers creating extra hours for academic programs to enable them clear the syllabus before the onset of the end of year form 4 national examinations, which is a tool used by the Ministry of Education to measure the teachers performance as per the subject mean grade attained in the teaching subject.

\section{Research Design and Population}

\section{RESEARCH DESIGN AND METHODOLOGY}

The study adopted descriptive survey research design.The design enabled the researcher to obtain information that provided reasons for poor performance at K.C.S.E level. The study population consisted of 33 Head teachers, 164 teachers and 1,035 form 4 students. Form four students were preferred because they have experience to suggest teacher behavior through observation.

\section{Sample and Sampling Procedure}

Simple random and systematic sampling method was used to select the 310 students. The 311 students were distributed among the 30 public secondary schools whereby 10 students were to be sought from each secondary schools using systematic method. The systematic sampling was used to select students at the interval of 5 from the register provided by the class teacher. The 10 students from each school were distributed equally with equal gender consideration. Teachers' were selected purposely from the list provided by the headteacher in the school 
selected. The longest serving teacher was preferred because he/she may be knowledgeable about the school. The respondents in the study will include 30 head-teachers purposively selected, 49 teachers and 311 Form 4 students in Suba Sub-County.

\section{RESULTS AND DISCUSSION}

\section{Teacher Workload Influence on Student's Academic Performance}

The aspects of teacher workload assessed include workload per week, workload and syllabus coverage and a regression analysis between workload and academic performance.

\section{Workload Per Week in Suba Sub - County Secondary Schools}

The government recommends a workload of 34 lesson per week. In Suba Sub - county the table 2 below reveals the number of lesson per week.

Table 2: Teacher Workload in Lessons Per Week

\begin{tabular}{lcccc}
\hline Workload & $\begin{array}{c}\text { Sub - county } \\
\text { Frequency(f) }\end{array}$ & Percentage & $\begin{array}{c}\text { Rating } \\
\text { score }\end{array}$ & $\begin{array}{c}\text { Mean } \\
\text { rating }\end{array}$ \\
\hline below 10 lessons & 1 & 2 & 1 & 1 \\
10-14 lessons & 2 & 4 & 4 & 2 \\
15-19 lessons & 12 & 24 & 36 & 3 \\
20-24 lessons & 19 & 38 & 76 & 4 \\
25-30 lessons & 16 & 32 & 80 & 5 \\
\hline Total & 49 & 100 & 197 & 3.94 \\
\hline
\end{tabular}

In this study those with 20-24 lessons per week were 38\%, 15-19 lessons per week at $24 \%$, 25-30 lessons per week at 32\%, 10-14 lessons per week at 4\% and 2\% have a workload of below 10 lessons per week. Therefore 47 respondents had a workload of 15- 30 lessons, at $94 \%$. The study also show that those with less than 10 lessons per week had very low influence , those with 10 - 14 lesson per week had low influence while those with above 15 lesson per week tended to have from moderate to high influence. In Suba Sub - county the average workload was 3.94 indicating that workload had high influence on academic performance. A similar study in New Zealand on teacher workload, Ingrarson et al, (2005) revealed that 48\% of the teachers felt that their workload was unmanageable, $57 \%$ could balance between home and work, $71 \%$ felt that their workload was affecting the quality of their teaching.75\% felt that their workload was heavy, 73\% felt that they could not do what they needed to do in reasonable time.21\% were thinking of leaving school because of the workload.36\% felt that they had little time to get to know their student's well.60\% felt that they had little time to provide professional support to colleagues, $28 \%$ were thinking of leaving teaching because it was adversely affecting their health. It further means that teachers should be given workload that they are able to manage and perform.

This study found out that a workload of 20-24 lessons per week translating to 16 hours per week, beyond which it impacts negatively on both the teacher and the student. The mean of the frequencies was 3.94; this was found out to be within the bracket of those who agreed that teachers would complete the syllabus despite the amount of workload.

In Kenya, teachers' workload is often measured by number of lessons taught by every teacher or the teacher contact hours in a week or the class size in terms of the actual and recommended workload. In Kenya, public schools have lower workloads than in other African Countries. For instance, the Mozambique case is 25 lessons and 2.5hours per week. A study by Siniscalo on comparison of Kenya with Asia and European countries showed that the actual 
and recommended teaching load of Kenyan Teachers is Lower (Siniscalo, 2002). The lower workload contradicts the teacher shortage experienced in some schools due to structural imbalance in the demand and supply of school teacher's. the world bank suggest that existing teachers could be utilized more efficiently by having teachers teach multiple subjects and sharing teacher's across the schools. The ministry of education stipulates that average teacher pupils contact hours per week be 28 hours comprising 48 periods each of 40 minutes long (Abagi,1997).

Table 3 shows workload influence on academic performance. This study found that $45.2 \%$ head teachers agreed that teachers with maximum lessons per week were able to complete the syllabus by the end of term, 32.3\% strongly agreed, and $22.6 \%$ disagreed. A total of $75.7 \%$ head teachers agreed that teachers with maximum workload still completed the entire form four syllabuses by end of term three.

Table 3: Workload Influence on Academic Performance

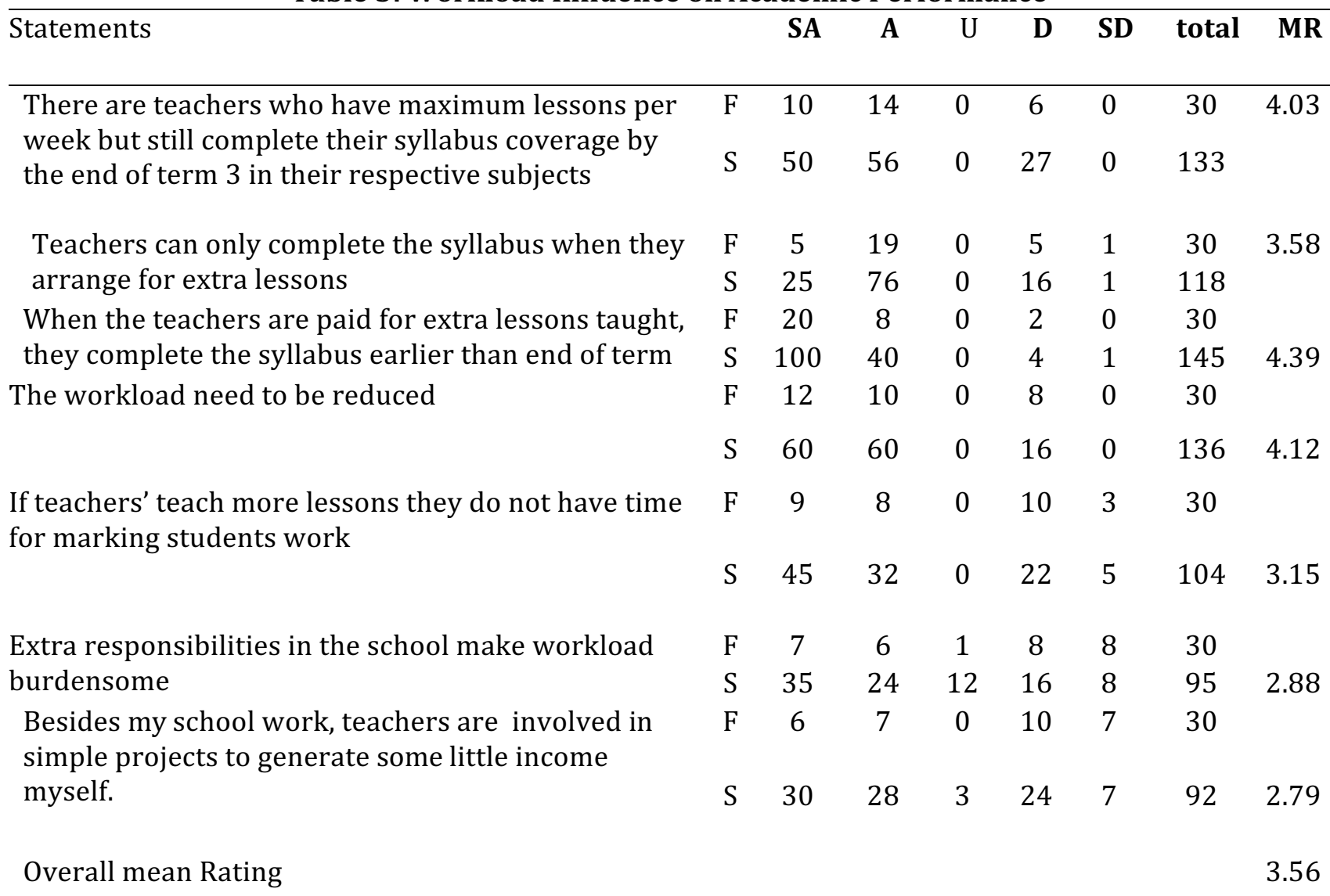

Key: $\mathbf{F}=$ Frequency $S=$ Score $\mathbf{T}=$ Total $M \mathbf{R}=$ Mean Rating

The average of the mean rating scores was found out to be 4.03 , indicating that the head teachers agree with the fact that teachers with maximum lessons per week do complete the syllabus by end of term three and hence had high influence. The headteachers also agreed that teachers can only complete the syllabus when they arrange for extra lesson. The mean rating was 3.58 indicating high influence.

According to headteachers, when teachers are paid for extra lessons taught, they complete the syllabus earlier than schedule. The mean rating was 4.39 indicating high influence. This may be true for teachers are motivated and perform their task with a lot of seriousness. According to headteachers, when teacher's are given more lesson than earlier recommended by the 
government, they may have little time for marking students work. This influences the academic performance at a mean rating of 3.15. Indicating moderate influence on academic performance. The study indicates that when teachers are given extra responsibilities their performance is low with mean rating of 2.88. It was also revealed by headteachers that most teachers in Suba sub County are involved in income generating project and this influences performance at mean rating of 2.79. At such mean rating, performance is dismal.

From this study, $61.3 \%$ of the Head teacher's response showed that teachers could only complete the syllabus by arranging for extra lessons, with 9.7\% strongly agreeing, 25.8\% disagreed and 3.2\% strongly disagreed. Therefore 22 head teachers at a percentage of $71 \%$ agreed that the teachers require extra time to complete the syllabus.This data infers that it is important for teachers to arrange for extra lessons to enable them clear the syllabus and revise with their candidates for KCSE examinations.

A similar study in India by Santhi (2011) revealed that extra classes have been a fixture in the educational system in India; that they pre-date all existing educational programs and examinations. Yet more recently the justification and reasons for the maintenance of these classes have been called into question. There have been unsubstantiated claims that in some cases the classes have been "organized" in some schools as a means to supplement some teachers' emoluments. This infers that extra lessons in India have existing school programs that are scheduled and paid for , and that teachers could only complete the syllabus if extra lessons are scheduled and paid for, in this study, it further means that there is need that the curriculum be checked and revised by KIE to determine if the syllabus is wide.

A similar study by Mutugi (2014) on factors affecting syllabus coverage in secondary schools in Langata district Nairobi revealed that $37.7 \%$ of the teachers were handling bigger classes which led to potential delay on syllabus coverage. She further added that $48.8 \%$ covered the syllabus in time because they had few subjects therefore a small workload.21.7\% indicated that they had many subjects therefore did not complete the syllabus in time.

In a similar study in Kenya by Eshiwani (2001)It is reported that in an attempt to improve performance, some parents arranged and pay for extra tuition for their children so that they may cover all topics within the curriculum, these topics included; Arithmetic, algebra, Geometry, Statistics, Navigation among others. Concepts in these topics are tested at K.C.S.E. Examinations. This therefore means the teachers need extra hours outside the school timetable, to cover the syllabus and embark on revision work in preparation for KCSE examinations. KCSE examinations in Kenya do begin early October leaving the student's with the month of September to revise, whereas the month of August is a holyday. The teachers are therefore left with the month of July or earlier to cover the entire syllabus and prepare the student's for KCSE examinations. This study found out that most of the teachers completed the syllabus by the month of May.

Most student's reported that Kiswahili, History, business-studies, physics and mathematics teachers rarely completed the syllabus; Kiswahili at 72.5\%, History at 70\%, business studies at $66.7 \%$ and Biology at $47.1 \%$. A study by Maurice et al, (2012) on investigation of factors that influence syllabus coverage in secondary schools with specific attention to Mathematics showed that schools coverage of syllabus co related positively with performance in the National KCSE examination and that syllabus coverage had a significant effect on student performance at KCSE. These explain the delay of syllabus coverage with specific concern to the perception of the teacher and the student's on the subject content. 
Table 4: Subject Where the Syllabus is Incompleted Due to Excess Workload

\begin{tabular}{|c|c|c|c|}
\hline Category & Subject & Frequency(f) & $\%$ \\
\hline \multirow[t]{2}{*}{ 1.Languages } & English & 88 & 27.5 \\
\hline & Kiswahili & 222 & 72.5 \\
\hline 2.Mathematics & Mathematics & 89 & 28.0 \\
\hline \multirow[t]{3}{*}{ 3.Sciences } & Biology & 146 & 47.1 \\
\hline & Chemistry & 36 & 11.8 \\
\hline & Physics & 126 & 41.2 \\
\hline \multirow[t]{3}{*}{ 4.Humanities } & Christian Religious Education & 31 & 10.0 \\
\hline & History & 217 & 70.0 \\
\hline & Geography & 62 & 20.0 \\
\hline \multirow[t]{3}{*}{ 5.Technical and Applied } & Business studies & 176 & 57 \\
\hline & Agriculture & 93 & 30 \\
\hline & Computer & 40 & 13 \\
\hline
\end{tabular}

The influence of teacher's workload on academic performance was also computed and regression analysis done. The computed results were shown as in table $5 \mathrm{a}, \mathrm{b} \& \mathrm{c}$

Table 5a Model Summary of Teacher's Workload and Academic Performance Model Summary

\begin{tabular}{|c|c|c|c|c|}
\hline Model & $\mathrm{R}$ & R Square & Adjusted R Square & Std. Error of the Estimate \\
\hline 1 & $.523^{\mathrm{a}}$ & .273 & .031 & .46433 \\
\hline
\end{tabular}

a. Predictors: (Constant), PERFORMANCE

Table 5a indicates that the influence of teacher's workload on academic performance was significant $(\mathrm{r}=.523, \mathrm{~N}=154, \mathrm{p}<0.01)$.

TABLE 5b ANOVAa

\begin{tabular}{|cl|c|c|c|c|c|}
\hline Model & & Sum of Squares & $\mathrm{df}$ & Mean Square & $\mathrm{F}$ & Sig. \\
\hline \multirow{3}{*}{1} & Regression & .243 & 1 & .243 & 1.127 & $.366^{\mathrm{b}}$ \\
& Residual & .647 & 3 & .216 & & \\
& Total & .890 & 4 & & & \\
\hline
\end{tabular}

a. Dependent Variable: WORKLOAD

b. Predictors: (Constant), PERFORMANCE

Table 5c Coefficientsa

\begin{tabular}{|cl|c|c|c|c|c|}
\hline \multicolumn{2}{|l|}{ Model } & \multicolumn{2}{|c|}{ Unstandardized Coefficients } & $\begin{array}{c}\text { Standardized } \\
\text { Coefficients }\end{array}$ & \multirow{2}{*}{$\mathrm{t}$} & \multirow{2}{*}{ Sig. } \\
\cline { 3 - 5 } & & $\mathrm{B}$ & Std. Error & Beta & & \\
\hline \multirow{2}{*}{1} & (Constant) & 6.709 & 2.731 & & 2.457 & .091 \\
& PERFORMANCE & -.558 & .525 & -.523 & -1.062 & .366 \\
\hline
\end{tabular}

a. Dependent Variable: WORKLOAD; equation $Y=\beta_{0}+\beta_{1} X_{1}+\varepsilon$

To establish the actual influence of parental education level on academic achievement of pupils, linear regression analysis was computed. Table 5c presents the linear analysis. The table indicates that for every one unit increase teacher workload, there was a decrease in pupils academic achievement as signified by the coefficient $(-.558)$. The regression equation $Y$ $=6.709-0.558 \mathrm{X}_{1}+\varepsilon$. 


\section{CONCLUSION}

The research found out that teachers workload affected students academic performance; whereas others complained of adverse effects on their time and health and negative impact on their productivity in class, another group were able to manage, balance, and consequently ensure the student's academic achievement was attained. Workload was therefore seen as a teacher perception towards job satisfaction. The head teacher's involvement in adequate staffing would reduce high workload and ensure that the students are taught and not given assignments while the teachers are absent. This would further ensure that class teachers and Heads of Departments are not over burdened by responsibilities. The study therefore concludes, teachers' workload influenced student's academic performance in secondary schools in Suba Sub-County,

\section{RECOMMENDATIONS}

The study recommends that the Teachers Service Commission who is the employer of teachers should ensure that the teachers are well paid, this is because the study found out that teachers preferred monetary motivation as a drive to clear the form four syllabus by term one and embark on revision. It further suggests that extra lessons should be scheduled and paid.

\section{ACKNOWLEDGEMENT}

The writing of this thesis would not have been accomplished without the encouragement, contribution and inspiration of other people. My family members especially my loving husband and children for encouragement and understanding they had during this period. My special thanks go to my two supervisors Dr. James Sika and Dr. Z. Wanzare for the professional advice and direction that they gave. On the same note am also indebted to Dr. Julius Gogo for the constant encouragement and not forgetting, the principals, teachers, parents and students of secondary schools in Suba Sub County who provided the vital information that I needed. May God bless you all.

\section{ABOUT THE AUTHORS}

1. Adika Berda Rose. The corresponding author. Is a researcher at the department of education management and foundation where she pursuing her masters degree in education administration, maseno university and Currently employed by teacher service commission as headteacher, Gwasi girls high school in Suba Sub - County, Kenya

2. James Ochieng Sika. Lecturer, Planning and Economics of Education, Department of Education Management and Foundation, Maseno University. Previously worked with ministry of education as quality assurance and standards officer and with teacher service commission.

\section{Refferences}

Abagi, O(1997) "The Impact of Politicised Education Reforms on Quality OF Primary Education: Experience for Kenya" In Watson, K et al. Educational Dilemmas: Debate and Diversion. London: Cassel

Ajzen, I \& Fishbein, M (1991): Attitudes and the Attitude- behavior Relation: Reasoned and Automatic Process. In W.Stroabe \& M.Hewstone(eds.), European Review of Social Psychology.NewYork:Wiley.

CEMASTEA(2012) “Effective Implementation of SMASE Primary activities”, CEMASTEA, Kenya

Chaudhury, N; Hammer, J; Kremer, M; Mvalidheran, K and Rogers, H.F (2006) Missing in Action: Teacher and Health Worker Absentees in Developing Countries: Journal of Economic perspectives: Vol.20 No.1 winter 2006 pg.91 - 116

Eshiwan, G(1993). Education in Kenya since Independence. Nairobi: East Africa Educational Publishers,1993 
Fishbein, M \& Ajzen, I.(1999). Belief, attitude, intention, and behavior: An introduction to theory and Research. Reading, MA: Addison- Wesley.

Ingrarson, L, et al (2005), Reduction of teacher workload, Messy university (1995). In study on teacher workload by the Newzealand PPTA. New Zealand.

Koech, S; Tikoko, B and Chemwei, B (2014). Institutional Factors that Influence Teacher Turnover in Public Secondary Schools in Baringo District, Kenya. International Journal of Education and Reference Vol.2 No.4

Kothari C.R (2004) Research Methodology: Methods and Techniques. New Delhi, New Age International

Maslach, C. (1999). Burnout: The cost of caring. Englewood Cliffs, NJ: Prentice: London

Maurice, A; Musasya, R; Shikuku, B and Duncan, W (2012) Science and Mathematics Education Department, Masinde Muliro University of Science and Technology on investigation of factors that influence syllabus coverage in secondary schools. Kenya

Ministry of Education(2015); Homa - bay County Education Office

Moore,W\&Esselman,M. (1992). Teacher efficacy, power, school climate and achievement: A Desegregating district's experience. Paper presented at the annual meeting of the American education Research association: San Francisco Mujs, D \&Reynolds, D.(2001). Effective teaching evidence and practice.London:Paul Chapman Publishing.

Mugenda, O. M., \& Mugenda, A. (2003). Research methods: Quantitative and qualitative approaches. Nairobi: Acts press.

Mutugi, T (2014). Factors affecting syllabus coverage in secondary schools in Langata district Nairobi,

Ngechu,M (2004): Understanding the Research Process and Methods. An Introduction to Research Methods. Nairobi. Acts Press.

New Zealand Council for Education Research (2000): National survey of Secondary Schools.

New Zealand Ministry of Education,(2000):Research and evaluations reports of Je Hiringa, Te Mahara. Auckland, NZ,Auckland University press.

Orodho, J. (2005). Techniques of writing research proposals and reports in Education and Social Sciences: Nairobi Kenya.

Price Waterhouse Coopers, (2011). The teacher workload study for the (UK) DFES. UK

Santhi, N (2011) A study on absenteeism of Employees in Retailing Industry. International Journal of Research in Commerce and Management. VOL.2 